VESA IITTI

\title{
The Fourth Way in Finland
}

\section{General Notes about the Fourth Way}

The Fourth Way, or simply 'the Work', began as a Greco-Armenian man named Georges Ivanovich Gurdjieff (1866?-1949) gathered groups of pupils in St Petersburg and Moscow in 1912. To these groups, Gurdjieff started to teach what he had learned and synthesized between ca 1896 and 1912 during his travels on spiritual search of Egypt, Crete, Sumeria, Assyria, the Holy Land, Mecca, Ethiopia, Sudan, India, Afghanistan, the northern valleys of Siberia, and Tibet (Webb 1980: 40-1, 43-4, 74).

In 1917 Gurdjieff and a handful of his mainly Russian pupils moved away from Russia as the conditions for their work got too difficult due to the Bolshevik revolution that took place later during the same year. The group travelled by foot to Essentuki in the Caucasus, and from there to Tiflis; the next places where they travelled and stayed were Constantinople and Berlin. After that, they settled permanently in Paris where Gurdjieff founded the Institute for the Harmonious Development of Man in 1922 (Lindsay 2005: 3710).

From 1922 and up to 1949, Gurdjieff travelled in Europe and the United States to introduce and further his ideas; he also wrote his three major works, consisting of ten books divided into a three part series. These are called All and Everything, Meetings with Remarkable Men, and Life is Real Only Then, When "I Am" (Webb 1980: 18). In addition to these works Gurdjieff wrote a smaller book The Herald of Coming Good which was published in 1933, introducing his ideas and the Institute. It was the only work published during his lifetime (Speeth 1989: 15-17), and even as such one that was not available for long, as Gurdjieff soon withdrew the book from the market. Gurdjieff's work also consists of one ballet, about 250 sacred dances, or movements, as well as about 200 piano compositions he made with his student Thomas de Hartmann (Gurdjieff Studies Internet site).

Neither Gurdjieff nor any of his disciples called themselves a church, a sect, or anything alike, but referred to themselves simply as 'the Work', 
or as 'the Fourth Way' (Webb 1980: 18; Melton 2001: 676). The name 'the Fourth Way' originates in a Gurdjieffian view that there are essentially three traditional ways of spiritual work: those of a monk, a fakir, and a yogi. These ways do not literally refer to the activities of a monk, a fakir, and a yogi, but to similar types of spiritual work emphasizing exercise of emotion, body, or mind. Those in the Fourth Way think that in their work all of these sides are equally present and that all sides need to be practised simultaneously - and in the circumstances of everyday life, not in some special conditions separated from it (Speeth 1989: 54-6, 69-70; Melton 2001: 676, 586-7). This kind of work with oneself includes intellectual study, self observation, daily meditation, movements, or sacred dances, co-operative efforts of various kinds, and arts, crafts, or manual labour (Speeth 1989: 3, 69-70, 83-8, 91-3; Melton 2001: 586-7; Lindsay 2005: 3711).

Gurdjieff's teaching is a blend of various influences that include Sufism, orthodox Christianity, Buddhism, Kabbalah, and general elements of various occult teachings of both the East and the West (Speeth 1989: 4-11). It is a unique combination of cosmology, psychology, theory of evolution, and overall theory and practise aiming to help individuals in their efforts towards what is called 'self-remembering'. The basic idea of the Work is that human beings as they are, are 'asleep', not truly having a free will, a unified self, or an ability to 'be and to do'. In this, the Fourth Way is reminiscent of the behaviourist school of psychology, which was influential around the time Gurdjieff started to teach his ideas at his Institute. The Fourth Way differs from the various forms of behaviourism in that according to its view, a person still has, regardless of his profound mechanical nature regarding outer stimuli, a possibility to a relatively free will, an ability to truly be and to do as a free agent with the aid of the conscious Work that he can do on himself (Speeth 1989: $43,31-3,50$ ).

The Work, or the Fourth Way, has been of enormous importance for New Age spirituality, or Western esotericism in its many forms since its formation in the early twentieth century, as is explained, for example, by Paul Heelas in his The New Age Movement, the Celebration of the Self and the Sacralization of Modernity (1996), and in entries in the Dictionary of Gnosis and Western Esotericism, Encyclopedia of Occultism and Parapsychology, and Encyclopedia of Religion. After the founder's death in 1949 the Fourth Way has continued to exist both in Europe and the United States via the Gurdjieff Foundation and other groups (Speeth 1989: 98-114; Melton 2001: 676-7, 587; Lindsay 2005: 3711; Gurdjieff Foundation internet site). The literature on the teachings and history of 
Gurdjieff and his pupils is growing, and there are currently some fifty memoirs and studies on Gurdjieff and his legacy, and the number of the Fourth Way practitioners can be counted in thousands (Speeth 1989: 95-100; Gurdjieff Studies Internet site). The main symbol of the Fourth Way, the enneagram, has, since its introduction by Gurdjieff in the early twentieth century, found its way also outside of the Fourth Way groups and their work-nowadays there are groups using it solely for popular personality tests and the like. Also in Finland there is such an organization, Suomen Enneagrammi ry, an organization that was registered in 1996 (Suomen Enneagrammi ry. internet site). The Fourth Way groups themselves do not view these kinds of enneagram groups and their literature very favourably, as is evident from, for example, Finland's Fourth Way Internet site where they are labelled as an 'entertainment' and a 'fad' (Neljäs Tie Suomessa internet site).

According to historian James Moore, the Fourth Way as a field of academic study 'has been neglected for decades but is suddenly becoming more fashionable' (email to the author on 12 August 2007). At this point, I have no exact numbers of academic studies done on Gurdjieff, the Fourth Way and subjects directly related worldwide; but when it comes to Finland, not even Master's theses have been written on the subject yet, despite Gurdjieff's great influence on New Age spirituality in the West and the movement's existence in Finland since the early 1970s. I am currently working on such a study, which is a case-study of a local Turku-area Fourth Way senior who has been active in the movement since the early 1970s. This article, however, focuses on the general history of the Fourth Way in Finland.

\section{The Fourth Way in Finland during Gurdjieff's Lifetime}

Information about Finns involved with the Fourth Way during Gurdjieff's lifetime is very limited. There are no records of groups who might have been working with the Fourth Way ideas in Finland during that time, nor of Finns who might have visited the Institute for the Harmonious Development of Man at Fountainebleau in France during the years of its existence (the only exception to this is discussed below). There are only five Finns who have been mentioned in Fourth Way emic-literature regarding this phase:

Dr Leonid Robertovich de Stjoernvall, a psychiatrist (1872-1938) (Moore 2005) and his wife Elizabeth Stjoernvall, linguist (Moore's e-mail message to the author on 13 August 2007) are undoubtedly the most notable Finns 
involved with the Fourth Way during Gurdjieff's life. Leonid became Gurdjieff's pupil in 1914 (Moore 2005) and remained a very devout one until his death. According to the historian James Webb, Leonid's wife said that her husband 'harboured an almost fanatical devotion, "almost a slave-like"' ' to Gurdjieff. 'He was only second to Ouspensky in drumming up recruits' and he was 'the oldest follower' of Gurdjieff (Webb 1980: 136, 262). The historian James Moore has called Leonid Stjoernvall Gurdjieff's 'doyen' (Moore 1991: photoplates).

Stjoernvall's son, Nikolai de Stjoernvall (later Nicholas de Val, born 1917) is a biological child of Gurdjieff. He is currently living in Geneva, the city where his mother Elizabeth also lived after Leonid's death. Nikolai later wrote the book Daddy Gurdjieff: Quelques souvenirs inédits (Daddy Gurdjieff: a Few Unedited Memories) in French, published in 1997, which did not give a very favourable picture of Gurdjieff, although it was not utterly negative either. According to Paul Beekham Taylor, Nikolai accompanied Gurdjieff to New York in 1929 when he was twelve years old (Beekham Taylor 2001: 176). According to my informant, Nikolai did his military service in Finland at some point, and Gurdjieff thought that Nikolai could have become a teacher in the Work. Nikolai decided otherwise, and thus Finland did not get a teacher of the Work who would have been linked to the source of the movement in more ways than one. He still speaks Finnish, with a notable Russian accent. ${ }^{1}$

The Stjoernvalls held meetings in Finland at 'their house, in the homes of his [Leonid's] patients, and occasionally in the Finnish dacha of one particularly well-off lady, a Madame Maximovitch' (Webb 1980: 136).

Madame Maximovitch has been mentioned only in the previous short quote on her and there is no more information available of her. Accordingly, it is not known whether she was actively involved with the Fourth Way or not.

A Buddhist monk, Thomas de Hartman, one of Gurdjieff's central pupils during this phase, in his book Our Life with Mr. Gurdjieff mentioned encountering a Finnish Buddhist monk near a city called Maikop in the Caucasus area. That part of the book tells of the monk being on his way back to Finland, making vegetarian food and speaking in horror 
about seeing hanged people earlier during his travels. The monk is not mentioned by name and there is no more information available on him (de Hartman 1972: 57). Evidently, though, that Finn was not involved with the Fourth Way.

It might well be the case that no other Finns than the Stjoernvalls visited the Institute, but there might have been Finns more or less actively taking part in the Fourth Way work in Finland during Gurdjieff's life. After all, Gurdjieff, Ouspensky, the Stjoernvalls and some others had, according to records, meetings in Finland during this phase.

Other Finland-related Fourth Way notes from this phase include Gurdjieff's best known pupil P. D. Ouspensky's strong and quite well documented 'telepathic experience' with Gurdjieff in Finland. Dr Stjoernvall was also present when this occasion started to unfold according to James Webb. The group stayed in Finland for three days during that visit to the country (Webb 1980: 149).

\section{The Fourth Way in Finland after Gurdjieff's Death}

Based on the written materials available ${ }^{2}$ and my interviews with two Fourth Way practitioners ${ }^{3}$ who have been active in the movement in Finland since the 1970s, the question of the Fourth Way in Finland after Gurdjieff's death can be meaningfully framed in two ways: firstly, regarding timeline and secondly, regarding 'teaching lines'. Many Fourth Way practitioners pay special attention to these teaching lines-who has passed on the teaching and to whom. Essential to these teaching lines is also that they can ideally be traced back all the way to Gurdjieff himself. Another of my informants said that without such a direct teaching line reaching back to Gurdjieff the work is at its time of seeking, on its way to get the needed full teaching line in order to be fully authentic. ${ }^{4} \mathrm{Next}$, I will frame the Fourth Way in Finland after Gurdjieff's death according to the two lines mentioned above.

2 Finnish Fourth Way publications by Karatas-Kirjat from the 1970s and 1980s as well as the websites of the Finnish Fourth Way seniors, available through 'Neljäs Tie Suomessa' internet site.

3 Interviews done in June-July, 2007.

4 Informant no. 2, interview done in July, 2007. 
1. Regarding the timeline:

a) $1970-80 \mathrm{~s}$

b) 2001-present.

2. Regarding the 'teaching-lines':

a) The Bennett line. J. G. Bennett (1897-1974) was a British mathematician, scientist, industrial research director, and an author, most known from his writings dealing with the teachings of Gurdjieff. Bennett met Gurdjieff in Istanbul in 1921 and helped him in establishing the Fourth Way in England. During Gurdjieff's life, in 1941, Bennett founded the Institute for Comparative Study of History, Philosophy, and the Sciences at Coombe Springs close to London. For a period of time he was also involved with the Subud movement and became its co-founder in England. After Gurdjieff's death Bennett founded what was called an Academy for Continuous Education at Sherborne, Gloucestershire in 1971 (Melton 2001: 170; Lindsay 2005: 832-3; Bennett 1997: 300-3, 308).

The Bennett line of Gurdjieff's teachings surfaced in Finland in the early 1970s via Väinö Kopponen who was in contact with Bennett and who took part to Bennett's seminar in the UK in the early 1970s. The group that met and worked under Kopponen's direction in Turku and Jämsä, both in the South-West of Finland, at its largest consisted of 20-30 people. The group attracted interest for example via the Fourth Way related articles that were published in the Finnish New Age magazines Ultra and Elonpyörä during that time. Kopponen arranged classic Gurdjieffian movements, or sacred dance-presentations to the Turku group sometime in the early $1980 \mathrm{~s} .{ }^{5}$ According to one of my informants, ${ }^{6}$ it is possible that Kopponen travelled to France in the 1950s and met Jeanne de Salzmann there, who were among Gurdjieff's main pupils during his lifetime, and who had been thought to take Gurdjieff's central place in the Fourth Way after his death in 1949.

The Finnish Bennett line of teaching started to publish Bennett's translated works already in 1969 via the Karatas-Kirjat (Karatas Books) publishing house, founded in Lahti. The next year, in 1970, the KaratasSeura (Karatas Society) was founded in Turku to further the teachings of Bennett and Gurdjieff in Finland. The Bennett line was the only line of teaching that was fully present in Finland before the Gurdjieff line

5 Interviews with informants nos. 1 and 2 in July 2007.

$6 \quad$ Notes from discussion with informant no. 3 in July 2007. 
of teaching emerged in the late 2001. The Bennett line, as well as the Karatas-Seura and Karatas-Kirjat, existed from the 1970s to the mid 1980s. Even after that there were at least two efforts to revive the teaching line by two of this line's senior students. Around the time this line of teaching was closing it had moved from its original main cities of Turku and Jämsä to Helsinki and Jyväskylä, and possibly also to Lahti. ${ }^{7}$

In relation to the Bennett line of teaching the then Lahti-based Ionowaseura ry (Ionowa Society), founded in 1970, must also to be mentioned. The Society, which still exists, maintains the legacy of a Russian mystically inspired visual artist, Aleksandra Ionowa (1899-1980). The Bennett line students as well as others interested in Gurdjieff's ideas had close relations to this society, and Ionowa's art was used in Finnish translations of Bennett's books. ${ }^{8}$

b) The Ouspensky line. P. D. Ouspensky (1878-1947) was a Russian journalist and philosopher who met Gurdjieff in St Petersburg in 1915 (Melton 2001: 1158). He can be argued to be the most important figure in the Fourth Way after Gurdjieff due to his highly influential writings and other work for the movement (Webb 1980: 93; Melton 2001: 685). He dissociated himself from Gurdjieff after the Institute for Harmonious Development of Man was established in France. At this point Ouspensky thought he could not understand his former teacher anymore. After splitting with Gurdjieff, he still continued to teach the Fourth Way as he understood and interpreted it in London for his own group and he also wrote about the Fourth Way (Melton 2001: 1158). His probably most known title is In Search of the Miraculous, which gives a fairly good general overview of Gurdjieff's teachings (Lindsay 2005: 6935).

The Ouspensky line appeared in Finland via Doctor Kari Krohn from the late 1960s to the early 1970s. He translated Ouspensky's The Psychology of Man's Possible Evolution into Finnish (Ihmisen sielulliset kehitysmahdollisuudet, Karatas-Kirjat 1970) and was the personal doctor of the Bennett line founder Väinö Kopponen. ${ }^{9}$ Another notable person in this line is Timo Kurki-Suonio who has translated Ouspensky's In Search of the Miraculous into Finnish (Sirpaleita tuntemattomasta opetuksesta). The

7 Informant no. 2, notes from a phone conversation, August 2007, and an e-mail on 14th of August to the author.

8 Informant no. 2, field-notes from discussions in July-August 2007, an e-mail on 14th of August to the author.

$9 \quad$ Notes from a meeting with informant no. 2 in July 2007. 
book had been translated into Finnish during the 1970s, but was eventually published only in 2004. A manuscript of the book was used by the Gurdjieff line Helsinki group soon after its formation in late 2001, and according to an informant of that group, the Helsinki group most likely also had a significant role in the book getting published..$^{10} \mathrm{It}$ is not certain whether the Ouspensky line of teaching was in direct contact with Ouspensky himself. My informant still deemed it relevant to name the existence of this line in Finland due to Krohn's and Kurki-Suonio's notable involvement in the translation and publication of Ouspensky's writings.$^{11}$

c) The Gurdjieff line. The Gurdjieff line of teaching is the most important of the teaching lines, not only because it provides a teaching line reaching all the way back to Gurdjieff, but also because it is the most active, if not de facto the only teaching line in Finland currently. The Gurdjieff line arrived in Finland at the end of the year 2001. ${ }^{12}$ At that point the Gurdjieff Foundation was looking into the level of Fourth Way activity in different parts of the world, especially in Russia. In the process they found the Fourth Way internet site of one of my informants, established a contact, and after that the Gurdjieff line of teaching arrived in Finland. The American teacher of the line's teacher, was studying with Gurdjieff in the United States during Gurdjieff's life and was given a mandate to teach the work. ${ }^{13}$ In 2001 a group of this teaching line was founded in Helsinki and in 2002 in Turku, both in Southern Finland. The Suomen Gurdjieff-Seura ry (the Gurdjieff Society of Finland) was registered on 19th of December 2003 in Helsinki. ${ }^{14}$

Groups in Helsinki and Turku nowadays meet on a weekly basis (except during the summer), read and talk about Gurdjieff's or Ouspensky's texts, as well as talk about practices related to 'self-remembering' that the teacher has given to groups to work with. The Helsinki group has also arranged 'work days' and movements, or sacred dances, in Finland, with visiting teachers of movements from Norway and Denmark. In this, the groups aim to function with a full scale of group work pos-

10 Notes from a meeting with informant no. 2 in July 2007.

11 Informant 2, field-notes from discussions in July-August 2007.

12 Suomen Gurdjieff Seura ry. Internet site; notes from a phone conversation with informant no. 2, August 2007.

13 Notes from a phone conversation with informant no. 2, August 2007.

14 Informant no. 2, field-notes from discussions in July-August 2007. 
sibilities, as in the older groups of the line in the UK and the United States. The Finnish line of the teaching has active relations to groups of the same teaching line in Scandinavia, the United Kingdom, France, and the United States.

Many members of the Helsinki and Turku groups have also taken part in Fourth Way activities in Denmark during recent years (since 2001). The Helsinki group also commemorates Gurdjieff's death in October (close to 29th), and celebrates Gurdjieff's birthday on 12th of January each year. Currently there has also been discussion about forming a group in Tampere, which indicates that interest in the Fourth Way is growing in Finland and broadening outside the South-Western area of the country (Suomen Gurdjieff Seura internet site; author's field notes).

\section{Summary}

The Fourth Way, a notable New Age, or Western esoteric movement founded by the Greco-Armenian G. I. Gurdjieff in the early twentieth century, was geographically close to Finland in its beginning, but paradoxically in the early phase of the movement only three Finns are known to have been involved with it. These three persons were Dr Leonid Robertovich deStjoernvall, his wife Elizabeth, and Nikolai de Stjoernvall, whose mother was Elizabeth de Stjoernvall and whose father was none other than Gurdjieff himself. Leonid was a devout pupil of Gurdjieff to the end of his life. After these three Finns, the next historically known Finn in the Fourth Way appears only in the late 1960s: doctor Kari Krohn who translated P. D. Ouspensky's Psychology of Man's Possible Evolution into Finnish and got it published, and Väinö Kopponen, who visited J. G. Bennett's Academy for Continuous Education in the UK in the early 1970s and started a group mainly in the Turku area of Finland soon after that. That line of teaching, the Bennett line, and the Karatas-Seura (Karatas Society) that was founded in 1970 to further its aims, lasted until the mid 1980s. After that the Gurdjieff line of teaching surfaced in the Helsinki area in 2001. Suomen Gurdjieff-Seura ry (The Finnish Gurdjieff Society) was founded in 2003. Nowadays there are active groups in this teaching line in Helsinki and Turku, and a third group is possibly being formed in the Tampere area in central Finland. Altogether, this indicates that the Fourth Way is nowadays bigger than ever in Finland, although the number of its practitioners in the groups in the country is very modest, currently around 20 . 


\section{References}

\section{Literature}

\section{Bennett, John}

1997 Witness. The Story of a Search. Santa Fe, New Mexico: Bennett Books. Beekham Taylor, Paul

2001 Gurdjieff and Orage, Brothers in Elysium. York Beach, Maine: Weiser Books.

\section{Hartman, Thomas de}

1972 Our life with Mr. Gurdjieff. Harmonsworth, Middlesex: Penguin Books Ltd.

\section{Heelas, Paul}

1996 The New Age Movement: The Celebration of the Self and the Sacralization of Modernity. Malden: Blackwell.

Lindsay, Jones (ed.)

2005 Encyclopedia of Religion. 2nd edition. Farmington, Hills: Thomson Gale.

Melton, Gordon (ed.)

2001 Encyclopedia of Occultism and Parapsychology. 5th edition. Farmington, Hills: Gale Group.

\section{Moore, James}

1991 Gurdjieff, a Biography. The Anatomy of a Myth. Shaftesbury, Dorset, Brisbane: Element.

2005 Gurdjieff, George Ivanovich. In: Wouter J. Hanegraaff et al. (eds), Dictionary of Gnosis $\mathcal{E}$ Western esotericism. Rockport, MA: Brill Academic Publishers.

\section{Speeth, Kathleen}

1989 The Gurdjieff Work. Los Angeles: Jeremy P. Tarcher.

Webb, James

1980 The Harmonious Circle. An exploration of the lives and work of G.I. Gurdjieff, P.D. Ouspensky and others. London: Thames and Hudson.

\section{Internet Sites}

Gurdjieff Foundation: http:/ / www.gurdjieff.org/foundation.htm (accessed 1 August 2007).

Gurdjieff Study: http: / www.gurdjieff.org.uk/gs3.htm (accessed on 1 August 2007).

Neljäs Tie Suomessa: http:/ / www.neljastiesuomessa.net/index.php?id=0 (accessed 1 August 2007).

Suomen Gurdjieff Seura Ry: http://www.gurdjieff.fi/ (accessed 1 August 2007).

Suomen Enneagrammi Ry: http:/ / www.enneagramfinland.fi/ (accessed $1 \mathrm{Au}-$ gust 2007). 